Pak. J. Agri., Agril. Engg., Vet. Sci., 2021, 37 (2): 97-104

ISSN: 1023-1072 (Print), ISSN: 2663-7863 (Online)

https://doi.org/10.47432/2021.37.2.4

\title{
ASSESSMENT OF PHENOLIC COMPOUNDS, ANTIMICROBIAL ACTIVITY AND FREE RADICAL SCAVENGING POTENCY OF THREE SELECTED VEGETABLES
}

\author{
J. Mangi ${ }^{* 1}$, A. Jat ${ }^{1}$, N. Soomro ${ }^{1}$, A. J. Pirzada ${ }^{1}$ and A. R. Sidhu ${ }^{2}$ \\ ${ }^{1}$ Institute of Plant Sciences, ${ }^{2}$ Institute of Chemistry, \\ University of Sindh, Jamshoro, Pakistan
}

\begin{abstract}
Phytochemicals are compounds derived from plants that are assumed to have defensive role against certain disease. They have antioxidants, anticancer, antimicrobial, antifungal, antiviral, antithrombic and anti-inflammatory properties. They have a high specificity to boost the immune system and play important role in the metabolism of hormones. The current study is based on qualitative and quantitative evaluation of total phenolics contents, phenolic compounds, antioxidant potential, free and bound phenolic acids in selected vegetables available at the local market of Hyderabad, Sindh, Pakistan. Two different extraction procedures ultrasonic-assisted base hydrolysis extraction and sonication extraction were used. Total 13 phenolic compounds were found and quantified by highperformance liquid chromatography (HPLC), in which Ferulic acid was quantified in a higher amount of $16.71 \mathrm{mg} / \mathrm{g}$ in bitter gourd. Total phenolic contents were determined by using Perklin-Elmer lambda UV/Visible spectrophotometer and higher concentration was found in Bitter gourd $92.56 \mathrm{mg} \mathrm{100/g}$ as compared to Luffa and Brinjal with 79.03 and $66.56 \mathrm{mg} \mathrm{100/g}$, respectively. The antioxidant activity (DPPH assay) was measured at $\lambda \max$ of $517 \mathrm{~nm}$, results revealed that Bitter gourd possessed the higher antioxidant activity with $182.61 \mu \mathrm{Mol} / \mathrm{g}$ followed by Luffa and Brinjal with 112.94 and 82.96 $\mu \mathrm{Mol} / \mathrm{g}$. The total Flavonoid contents were higher in Brinjal with $44.32 \mathrm{mg} \mathrm{g}^{-1}$ whereas Luffa and Bitter gourd possess the Flavonoid concentration in the range 38.02 and $34.64 \mathrm{mg} \mathrm{g}^{-1}$ respectively, the total tannin contents also higher in Brinjal $31.40 \mathrm{mg} / \mathrm{g}$ follwed by in Luffa and Bitter gourd with 25.17 and $21.19 \mathrm{mg} / \mathrm{g}$ respectively. Antimicrobial activity showed that, all the extracts are the highly effective against $S$. aureus as compared to $E$. coli. Finally, it is concluded that all the selected vegetables are very good sources of Phenolic compounds as well as phytochemicals and should be included in the daily human diet for good health. On the basis of obtained results, it is also suggested that these samples will be further investigated for the determination of fatty acids by GC-MS and liquid chromatography-mass spectrum (LC-MS).
\end{abstract}

Keywords: antimicrobial activity, free radical scavenging (DPPH), HPLC-DAD, phytochemical

\section{INTRODUCTION}

The term vegetable typically includes consumable part of herbaceous plant, root, stem, leaves, flower, or fruits. Herbaceous are the non-woody plants that are cultivated in farms, home garden, kitchen gardens, gathered from backwoods tree and markets for the use of house (Eme-Okafor, 2016). Vegetables are the good source of fiber contain naturally low/no in fat/cholesterol and calories. They are rich in minerals and vitamins, phenolic acids, flavonoids, and glucosinolates, which act as antioxidants, blood sugar and blood pressure influencing substances. Vegetables contain various phytochemicals which have very

"Corresponding author: jamal.mangi@usindh.edu.pk important effects including, anticarcinogenic, antiviral, cholesterol-lowering, antifungal, antibacterial, antiinflammatory or antithrombotic (Jaiswal et al., 2011). However ever most of these functional compounds have wide ranges of these properties. For example, antioxidative phytochemicals are phenolic compounds, saponins, protease, inhibitors, carotenoids, sulfides, phytoestrogens, monoterpenes, and phytosterols (Duyn and Pivonka, 2000; TomasBarberan and Espin, 2001). The European Prospective Study of Cancer (EPIC) and World Cancer Research Fund/American Institute for Cancer Research, the Health Education Authority (UK), the German Nutrition Society, and the German Cancer Society suggested that an inclusion of $50 \mathrm{~g}$ and $375 \mathrm{gm}$ of vegetable in daily food intake lead to reduction in the $20 \%$ of 
Pak. J. Agri., Agril. Engg., Vet. Sci., 2021, 37 (2)

the premature death and healthy life (Khaw et al., 2001). It is also recommended that, the daily food intake should contain functional compound that are rich in the phytochemicals in conjugation with non-alcoholic and fat consumption (Boeing et al., 2004). Recently, It was reported that, various crop production practices were used to enhance the phytochemical content and composition in many vegetables and fruits (Vaccinium spp) (Eichholz et al., 2012; Schreiner, 2005). Hu et al. (2004) reported that, the mechanisms of natural antioxidant are not efficient therefore, use of antioxidant in the diet is important. These antioxidant are also widely used in the food industry to increase the shelf life of food specially those foods which are rich in the polyunsaturated fat (Isabelle et al., 2010). In addition, these antioxidant are also used in the processed food to prevent the lipid oxidation (Ayaz et al., 2008; Andarwulan et al., 2010).

Formerly, it was revealed that, the chemicals which are synthesize in the laboratory are highly costly and toxic. Morover due to increase in the awareness of consumer about feed additives, the information about safety, and natural source of antioxidant must be mentioned on product (Zhou and Yu 2006; Dasgupta, 2007). It is reported that, growth conditions and genotypes are the evidence to alter the different properties includings phytochemicals, antioxidant and antibacterial properties (Stangeland et al., 2009). From last two decades, plants and vegetable are the only natural source of phytochemical which pays attention of scientist to explore their chemical composition by using different methods and techniques. The present work also based on the same phenomena i.e in this work we determine phytochemicals analysis of selected local vegetables, their antimicrobial activity, and radical scavenging activity.

\section{MATERIALS AND METHODS} Chemicals, standards and vegetables

Fresh three selected vegetables Bitter gourd (Momordica charantia), Luffa (Luffa acutangular), and Brinjal (Solanum melongena) were collected from the local market of district Hyderabad Sindh, Pakistan during April and May 2020. All chemicals and reagents used in this research work were pure analytical grade.

\section{Processing of vegetable material}

The collected vegetables were washed with tape and then distilled water, to remove dust particles and dried in shade for 2 weeks, after drying each vegetable ground separately with an electric grinder and kept in different glass storage bottles that have clamp lids before analysis.

\section{Phenolic compounds evaluation}

Ultrasonic-assisted base hydrolysis extraction method was used in order to extract the phenolic compounds, $0.5 \mathrm{~g}$ of powdered vegetables was hydrolyzed with $10 \mathrm{ml}$ of base solution $(0.372 \mathrm{~g}$ EDTA, $2 \mathrm{~N}$ sodium hydroxide and $1 \mathrm{~g}$ of ascorbic acid) in $100 \mathrm{ml}$ polypropylene tubes by purging nitrogen $\left(\mathrm{N}_{2}\right)$ preceding covering. At that point, covered tubes were vortexed and sonicated for 30 minutes at $56^{\circ} \mathrm{C}$. After hydrolysis, the samples were cooled and acclimated to hydrochloric acid $(\mathrm{pH} 2.5)$, and the phenolic mixture were taken out with $5 \times 2 \mathrm{ml}$ of acidic ether (ethyl acetate $\mathrm{C}_{4} \mathrm{H}_{8} \mathrm{O}_{2}$ ) and then vertexed for 25-30 followed by centrifuged at 5,000 rpm for 10 minutes to separate the whole, aqueous layers and higher organic layer of phenolic compounds. After the solidification of phenolics compounds, they were dried by removing nitrogen followed by $5 \mathrm{ml}$ of $80 \%$ methanol was added. Finally, the solution was filtered via 0.45 $\mu \mathrm{m}$ syringe filters before HPLC investigation. The comparative concentrates were likewise utilized in favor of assessment of total phenolic contents (TPC) and antioxidant activity (Memon et al., 2013).

\section{Assessment of total phenolic contents (TPC)}

The quantification of total phenolic contents (TPC) assay was carried out by Folin-Ciocalteu (FC) reagent method with slight modification (Memon et al., 2012; Boakye et al., 2015). The reaction mixtures consist $0.2 \mathrm{ml}$ of diluted extracts, $0.8 \mathrm{ml}$ of Folin-Ciocalteu (FC) reagent and $2 \mathrm{ml}$ of sodium carbonate $\left(\mathrm{Na}_{2} \mathrm{CO}_{3}\right)$ Saturated solution $(7.5 \%)$. Finally, mixtures were filled with demonize water and adjusted the volume up to $7 \mathrm{ml}$ then for the completion of the reaction placed the mixtures in darkness at ambient temperature for 2 hours. After incubation time absorbance was measured on Perkin Elmer lambda 35, UV/Vis spectrophotometer at $765 \mathrm{~nm}$. The total phenolic content was calculated from a standard, the obtained results of various extracts were expressed as Gallic acid equivalents $(\mathrm{mg} / \mathrm{g})$.

Assessment of total Flavonoid contents Total flavonoid contents (TFC) were analyzed by reported method (Laghari et al., 2011). The reaction mixture was sonicated extract contains 
$2 \mathrm{ml}$ of sodium nitrite $(5 \% \mathrm{w} / \mathrm{v}), 0.5 \mathrm{ml} \mathrm{AlCl}_{3}$ $(10 \% \mathrm{w} / \mathrm{v})$ and $3 \mathrm{ml} \mathrm{NaOH}(4.3 \% \mathrm{w} / \mathrm{v})$ and distilled water up to $10 \mathrm{ml}$. After that, the solution was placed in the dark for 15 mins for completion of the reaction (Laghari et al., 2011), and the absorbance was measured on UV/VIS spectrophotometer, Perkin Elmer lambda 35, at 500 nm, $80 \%$ aqueous methanol was taken as reference, Rutin was used as a standard with the concentration range from $1-100 \mu \mathrm{g} / \mathrm{ml}$ The results were expressed as rutin equivalents (Rutin eq. $\mu \mathrm{g} / \mathrm{ml}$ ) and predicted from a standard curve.

\section{Evaluation of total tannin contents}

In brief, $0.2 \mathrm{~g}$ powder samples of each vegetable were extracted in $1 \%$ hydrochloric acid in methanol for 20 mins at $30^{\circ} \mathrm{C}$ then $1 \mathrm{ml}$ of extract and $5 \mathrm{ml}$ of vanillin reagent (50:50 mixture of $1 \%$ vanillin $8 \% \mathrm{HCl}$ in methanol) was treated for 20 mins at $30^{\circ} \mathrm{C}$ (Siddiqui et al., 2017), and the absorbance was measured on UV/VIS spectrophotometer, at $500 \mathrm{~nm}$. $\mathrm{HCl}(4 \%)$ as a substituent of vanillin reagent was added to the extract and used as a blank. While catechin was used for standard. The results were estimated by the standard curve of catechin which obtained in the concentration range 6.25 $\mu \mathrm{g} / \mathrm{ml}$ to $200 \mu \mathrm{g} / \mathrm{ml}$ (Siddiqui et al., 2017).

\section{Radical scavenging activity (RSA)}

Two $\mathrm{ml}$ of $0.1 \mathrm{mmol}$ of DPPH solution was mixed to $2 \mathrm{~mL}$ sonicated extract of every vegetable followed by shaking and placed in the dark for up to 25 minutes. The quercetin standards were prepared, and the range of concentration was used 1 to $10 \mu$ mol. Subsequently, the absorbance was determined through a UV/Vis spectrophotometer at $517 \mathrm{~nm}$. The antioxidant activity equivalent to quercetin was adapted from the standard curve and expressed as $\mu \mathrm{mol} / 100 \mathrm{~g}$ of the sample (Memon et al., 2013; Amron and Konsue, 2018).

\section{Identification and Quantification of phenolic compounds by (HPLC-DAD)}

HPLC Thermo Finnigan, SCM 1000 (California, USA) connected with a DAD (diode array detector) system was used for the analysis of phenolic compounds. Reverse-phase Hypersil Gold C-18 (Thermo Corporation, USA) was used to separate different phenolic compounds, (Memon et al., 2013). The gradient mobile phase solvent $0.1 \%$ formic acid in water $(A)$ and in methanol (B), were used. The rate of flow was kept as $1 \mathrm{ml} / \mathrm{min}$ and the gradient linear was $5 \%$ to $30 \%$ for $25 \mathrm{~min}$, followed by $30 \%$ for $45 \mathrm{~min}$, gradient linear elution was altered as of $30 \%$ up to $100 \%$ for 52 minutes. After 52 min, elution was carried back to $5 \%$ for $3 \mathrm{~min}$ in order to equilibrate the column. Furthermore, with the help of DAD, the UV analysis was done, set at 270, 310, and 325nm. The software Chromquest Version 4.2 was applied for data interpretation. All phenolic compound structures were separately confirmed by comparison their UV spectra and retention time (tR) with related standards. For the construction of each standard curve, the standard solutions in the different concentration series from $1-50 \mu \mathrm{g} / \mathrm{ml}$ were introduced into the HPLC-DAD system. The concentrations of the different phenolic constituents were calculated through peak area. In accordance with their individual standard curves.

\section{Determination of antimicrobial activities}

The antibacterial action of vegetables was determined by the strategy depicted by (Rahman et al., 2017). Four concentrations of $125,250,500$ and $1000 \mu \mathrm{gmL}^{-1}$ were set up in $100 \%$ DMSO (dimethyl sulfoxide), and DMSO was utilized as the negative control. Whatman No. 1 paper with $20 \mu \mathrm{L}$ of different obsessions (100\% diluted) was arranged outwardly of the petri dishes place in an incubation center for 24 hours at $37^{\circ} \mathrm{C}$. After that, the antibacterial movement estimating by the territory of hindrance width in $\mathrm{mm}$ around the circles and determined MIC (minimum inhibition concentration) values (Bouchekrit et al., 2016).

\section{RESULTS}

Twenty diverse phenolic guidelines (aldehyde, protocatechuic, vanillin, pyrogallol, ferulic, $m$ coumaric, 2,4,6-trihydroxy benzoic, $p$-coumaric, gallic acid, gentisic, $\beta$-resorcinolic, $p$ hydroxybenzoic, sinapic, vanillic, chlorogenic, hypogallic, caffeic, protocatechuic, o-coumaric, syringic, and, cinnamic acid) were run into a chromatographic segment of spectra frame work SCM 1000 instrument, with flow rate $1.0 \mathrm{~mL} / \mathrm{min}$ and, spectra were recorded at 325, 310 and $270 \mathrm{~nm}$. Every sample had a three replicate (Table 1). The HPLC profiling results revealed that, the presence of thirteen phenolic compounds i.e. Gallic acid, sinapic acid, Catechin, chlorogenic acid, Naringrin vanillin, vanillic acid, caffeic acid, $p$-hydroxybenzoic acid, ferulic acid, $m$-coumaric acid, $p$-coumaric acid, and cinnamic acid, were identified as bound phenolic compounds from selected vegetables which are given in (Table 2). 
Pak. J. Agri., Agril. Engg., Vet. Sci., 2021, 37 (2)

Table 1. Identification and Separation of phenolic standards with respective linearity and retention time by HPLC coupled with diode-array detector

\begin{tabular}{|l|l|l|l|l|}
\hline Standards & $\mathbf{t}_{\mathbf{R}(\mathbf{m i n})}$ & $\mathbf{\lambda} \mathbf{m a x}(\mathbf{n m})$ & $\mathbf{R}^{2}$ & Regression equation \\
\hline Gallic acid & 7.69 & 227,272 & 0.999 & $\mathrm{y}=305726 \mathrm{x}-249684$ \\
\hline $2,4,6-$ THBA & 9.51 & $216,255,292$ & 0.998 & $\mathrm{y}=49119 \mathrm{x}+29082$ \\
\hline Protocatechuic acid & 13.16 & $228,259,294$ & 0.997 & $\mathrm{y}=530511 \mathrm{x}+112990$ \\
\hline Pyrogallol aldehyde & 14.18 & 234,291 & 0.999 & $\mathrm{y}=337860 \mathrm{x}+147020$ \\
\hline Protocatechuic aldehyde & 14.35 & 234,281 & 0.998 & $\mathrm{y}=548015 \mathrm{x}+303632$ \\
\hline Naringinin & 14.92 & 232,327 & 0.999 & $\mathrm{y}=13444 \mathrm{x}-1829.4$ \\
\hline Vanilline & 17.26 & $233,281,307$ & 0.999 & $\mathrm{Y}=626260 \mathrm{x}-138097$ \\
\hline Sinapic acid & 19.92 & 255,294 & 0.991 & $\mathrm{y}=643555 \mathrm{x}-1 \mathrm{E}+06$ \\
\hline$\beta$-resorcinolic acid & 18.99 & 255,294 & 0.998 & $\mathrm{y}=200138 \mathrm{x}+46398$ \\
\hline Hypogallic acid & 19.61 & 232,314 & 0.998 & $\mathrm{y}=82657 \mathrm{x}-14787$ \\
\hline Vanillic acid & 27.19 & $223,260,294$ & 0.999 & $\mathrm{y}=289390 \mathrm{x}-82077$ \\
\hline Caffeic acid & 28.73 & 233,323 & 0.995 & $\mathrm{y}=169059 \mathrm{x}-140031$ \\
\hline Chlorogenic acid & 32.83 & $217,233,327$ & 0.998 & $\mathrm{y}=97008 \mathrm{x}-33773$ \\
\hline Syringic acid & 33.33 & 225,275 & 0.999 & $\mathrm{y}=214749 \mathrm{x}-72422$ \\
\hline Naringin & 34.8 & $232,283,327$ & 0.998 & $\mathrm{y}=37927 \mathrm{x}+35542$ \\
\hline$P$-HBA & 35.18 & 234,308 & 0.999 & $\mathrm{y}=88856 \mathrm{x}-14995$ \\
\hline$p$-coumaric acid & 40.45 & 232,309 & 0.995 & $\mathrm{y}=213962 \mathrm{x}-333316$ \\
\hline Ferullic acid & 46.79 & 235,322 & 0.998 & $\mathrm{y}=174006 \mathrm{x}+127640$ \\
\hline$m$-coumaric acid & 47.59 & $216,232,278$ & 0.999 & $\mathrm{y}=533000 \mathrm{x}+78590$ \\
\hline 0 -coumaric acid & 48.75 & $232,277,330$ & 0.999 & $\mathrm{y}=7 \mathrm{E}+06 \mathrm{x}-2 \mathrm{E}+06$ \\
\hline Cinnamic acid & 49.05 & $230,280,330$ & 0.992 & $\mathrm{y}=568487 \mathrm{x}+305505$ \\
\hline Rutin & 62.18 & $257,285,355$ & 0.999 & $\mathrm{y}=14303 \mathrm{x}-77826$ \\
\hline Gentisic acid & 63.8 & 235,287 & 0.999 & $\mathrm{y}=13791 \mathrm{x}-40728$ \\
\hline
\end{tabular}

$t_{R=\text { Retention time }}$

Table 2. Bound phenolic acids profiling from selected vegetables

\begin{tabular}{|l|l|l|l|l|}
\hline Phenolic acids & $\mathbf{t}_{\mathbf{R}(\mathbf{m i n})}$ & Bitter gourd $\mathbf{M g} / \mathbf{g} \pm \mathbf{R S D}$ & Luffa $\mathbf{M g} / \mathbf{g} \pm \mathbf{R S D}$ & Brinjal $\mathbf{~ g} / \mathbf{g} \pm \mathbf{R S D}$ \\
\hline Gallic Acid & 8.7 & $5.53 \pm 0.13$ & $5.65 \pm 0.12$ & $2.02 \pm 0.05$ \\
\hline Naringrin & 15.75 & $9.29 \pm 0.12$ & $3.15 \pm 0.11$ & $2.45 \pm 0.14$ \\
\hline Vanilline & 20.18 & $\mathrm{ND}$ & $5.77 \pm 0.13$ & $\mathrm{ND}$ \\
\hline Sinapic Acid & 23.71 & $4.95 \pm 0.02$ & $6.82 \pm 0.11$ & $1.52 \pm 0.01$ \\
\hline Vanillic Acid & 25.18 & $\mathrm{ND}$ & $3.66 \pm 0.09$ & $\mathrm{ND}$ \\
\hline Catechein & 27.39 & $\mathrm{ND}$ & $\mathrm{ND}$ & $2.11 \pm 0.12$ \\
\hline Chlorogenic Acid & 29.34 & $\mathrm{ND}$ & $\mathrm{ND}$ & $\mathrm{ND}$ \\
\hline Caffeic Acid & 32.98 & $7.47 \pm 0.12$ & $\mathrm{ND}$ & $4.56 \pm 0.16$ \\
\hline$P$-HBA & 35.18 & $2.43 \pm 0.01$ & $14.57 \pm 1.02$ & $\mathrm{ND}$ \\
\hline$P$-Coumaric Acid & 45.50 & $6.21 \pm 0.11$ & $\mathrm{ND}$ & $11.26 \pm 1.21$ \\
\hline$m$-Coumaric Acid & 47.59 & $\mathrm{ND}$ & $2.17 \pm 0.04$ & $\mathrm{ND}$ \\
\hline Cinamic Acid & 49.05 & $\mathrm{ND}$ & $\mathrm{ND}$ & $\mathrm{ND}$ \\
\hline Ferulic Acid & 51.16 & $16.71 \pm 0.23$ & $\mathrm{ND}$ & $5.78 \pm 1.11$ \\
\hline TBPA & & 52.59 & 41.79 & 29.70 \\
\hline
\end{tabular}

$t_{R=\text { Retention time. }} \mathrm{RSD}=$ Relative standard deviation, $\mathrm{ND}=$ Not detected

Figure $1(A)$ is the chromatogram of bitter gourd extract in which 7 phenolic compounds were identified. These compounds were Gallic acid $(5.53 \mathrm{mg} / \mathrm{g})$, Naringrin $(9.29 \mathrm{mg} / \mathrm{g})$, sinapic acid $(4.95 \mathrm{mg} / \mathrm{g})$, Caffeic acid $(7.47 \mathrm{mg} / \mathrm{g}), p-\mathrm{HBA}$ determined in lowest amount as $(2.43 \mathrm{mg} / \mathrm{g}), p$ coumaric acid $(6.21 \mathrm{mg} / \mathrm{g})$, and ferulic acid obtained in highest amount as $(16.71 \mathrm{mg} / \mathrm{g})$ at retention time 8.7, 15.75, 23.71, 32.98, 35.18, 45.50 and 51.16 minutes respectively.
Figure $2(A)$ is the chromatogram of luffa extract in which 7 phenolic compounds were identified. These compounds were Gallic acid $(5.65 \mathrm{mg} / \mathrm{g}), \quad$ Naringrin $(3.15 \mathrm{mg} / \mathrm{g})$, Vanillin $(5.77 \mathrm{mg} / \mathrm{g})$, sinapic acid $(6.82 \mathrm{mg} / \mathrm{g})$, Vanillic Acid $(3.66 \mathrm{mg} / \mathrm{g}), p$-HBA determined in highest amount as $(14.57 \mathrm{mg} / \mathrm{g})$, and $m$-Coumaric Acid obtained in low as $(2.17 \mathrm{mg} / \mathrm{g})$ at retention time 8.7, 15.75, $20.1823 .71,25.1835 .18$ and 47.59 minutes respectively. 
Figure $3(A)$ is the chromatogram of brinjal extract in which 7 phenolic compounds were identified. These compounds were Gallic acid $(2.02 \mathrm{mg} / \mathrm{g})$, Naringrin $(2.45 \mathrm{mg} / \mathrm{g})$, sinapic acid determined in lowest amount as $(1.52 \mathrm{mg} / \mathrm{g})$,
Catechein $(2.11 \mathrm{mg} / \mathrm{g})$, Caffeic acid $(4.56 \mathrm{mg} / \mathrm{g})$, $p$-coumaric acid obtained in highest amount as $(11.26 \mathrm{mg} / \mathrm{g})$, and ferullic acid $(5.78 \mathrm{mg} / \mathrm{g})$ at retention time $8.7,15.75,23.71,27.39,32.98$, 45.50 and 51.16 minutes respectively.

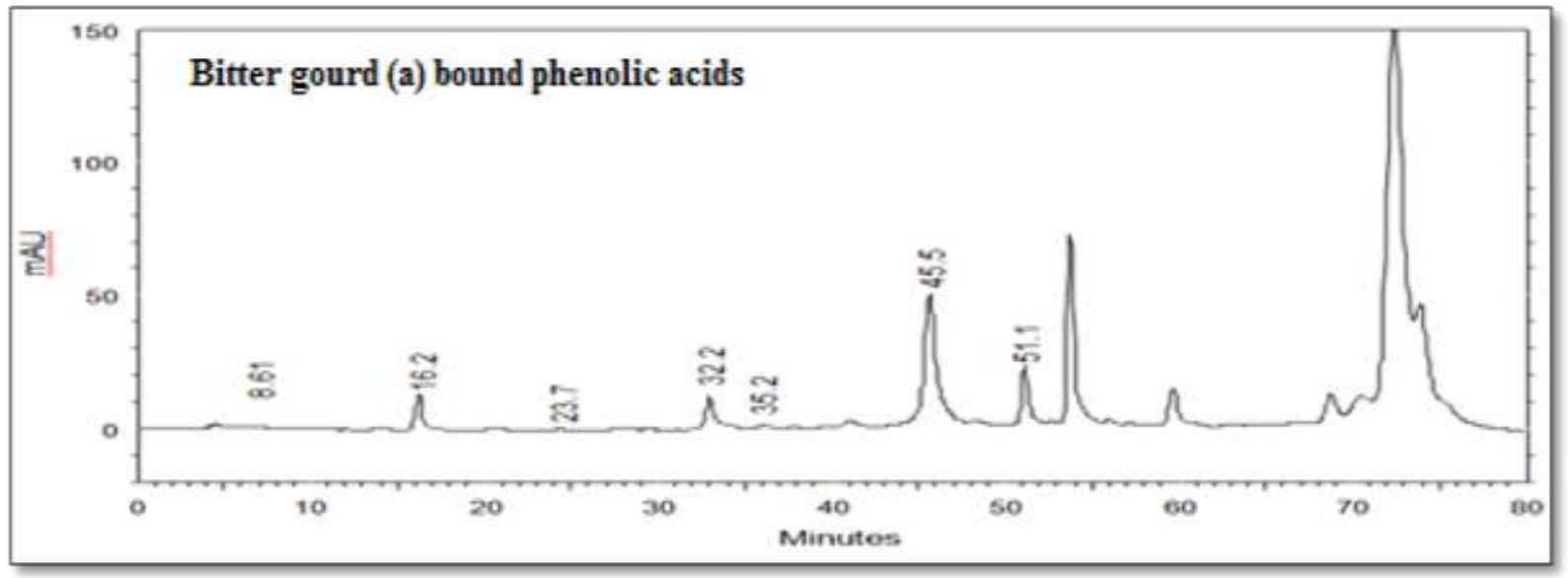

Figure 1. (A) HPLC chromatogram of bitter gourd

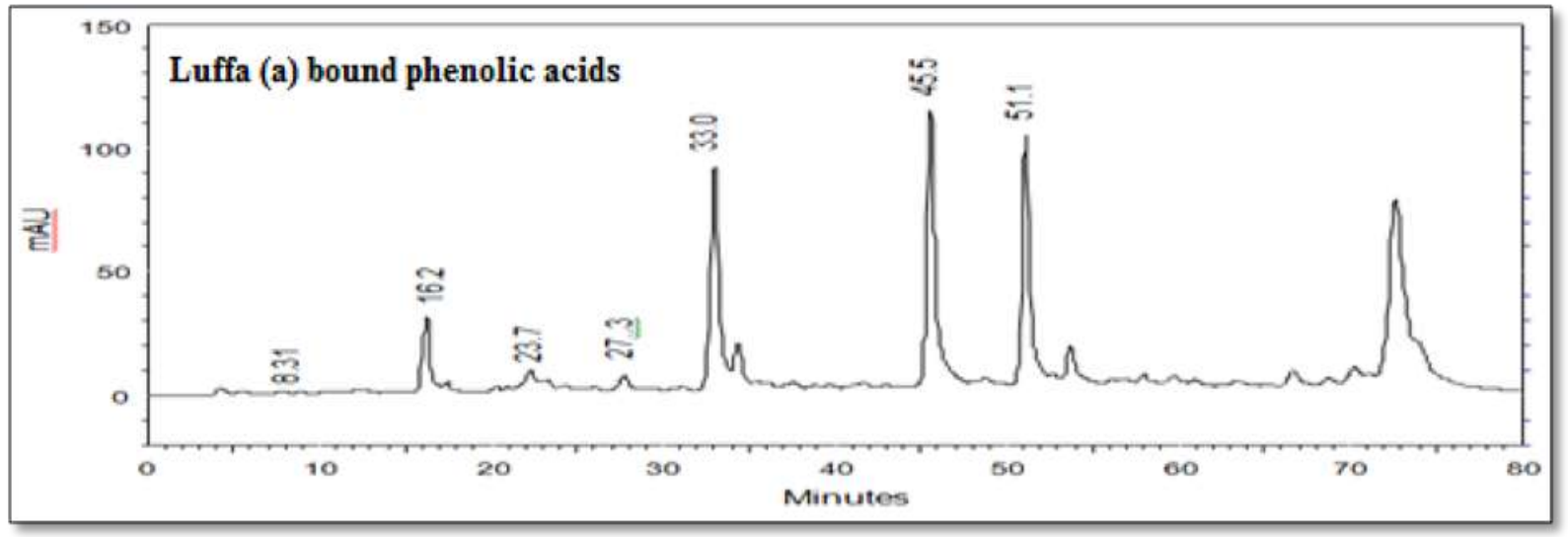

Figure 2. (A) HPLC chromatogram of luffa

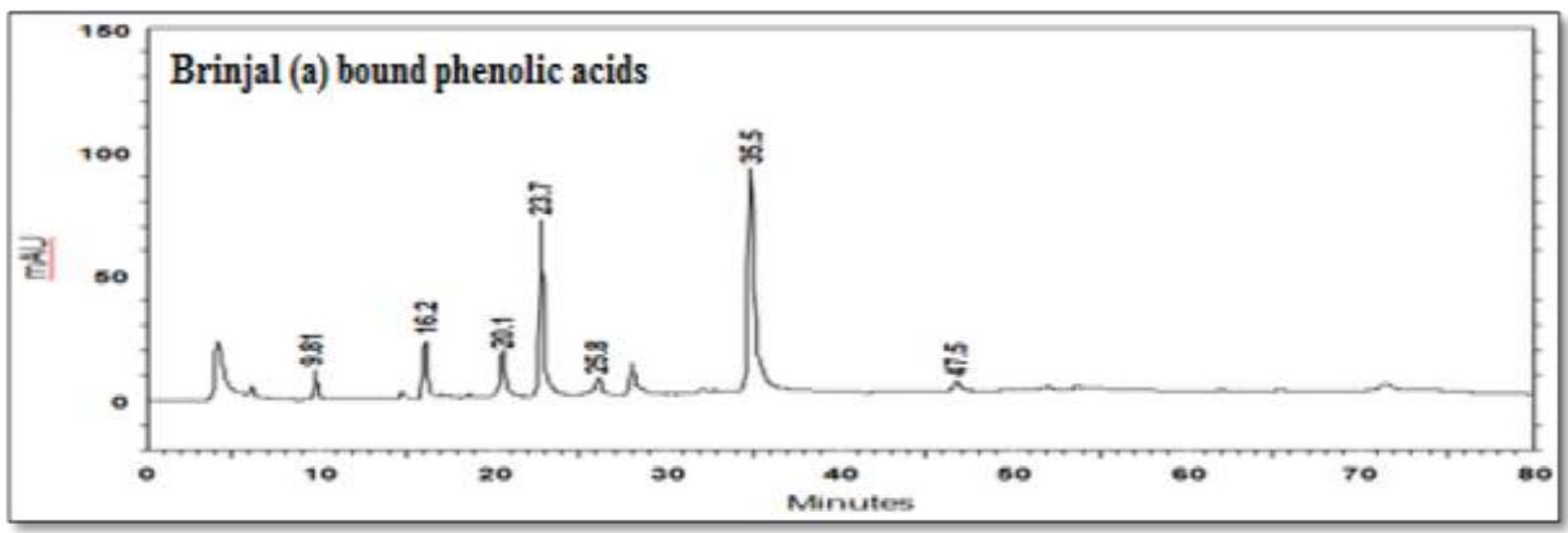

Figure 3. (A) HPLC chromatogram of brinjal 
Total Phenolic, Free radical scavenging activity, total flavonoid, and total tannin content of vegetables are shown in Table 3 . The highest total phenolic contents (TPC) are quantified in bitter gourd as $92.56 \mathrm{mg} / \mathrm{g}$ and lowest was in brinjal as $66.56 \mathrm{mg} / \mathrm{g}$ luffa possess the average value which is $79.03 \mathrm{mg} / \mathrm{g}$, the radical scavenging activity (RSA) was also greater in $182.61 \mu \mathrm{mol} / \mathrm{g}$ and smallest was in brinjal as $82.96 \mu \mathrm{mol} / \mathrm{g}$ again luffa possesses the average value of RSA as $112.61 \mu \mathrm{mol} / \mathrm{g}$, total flavonoid contents (TFC) are highest in brinjal which is $44.32 \mathrm{mg} / \mathrm{g}$ and smaller determined in bitter gourd as $34.64 \mathrm{mg} / \mathrm{g}$, TFC was $38.02 \mathrm{mg} / \mathrm{g}$ in luffa and total tannin contents (TTC) also find higher in brinjal $31.40 \mathrm{mg} / \mathrm{g}$ and lowest in bitter gourd as $21.19 \mathrm{mg} / \mathrm{g}$ and luffa possess 25.17 $\mathrm{mg} / \mathrm{g}$.

Table 3. Total phenolic content, anti-oxidant activity, total flavonoids content, and total tannins content

\begin{tabular}{|l|l|l|l|l|}
\hline Samples & $\begin{array}{l}\text { T.P.A } \\
(\mathbf{m g} / \mathbf{g})\end{array}$ & $\begin{array}{l}\text { RSA } \\
(\boldsymbol{\mu} \mathbf{m o l} / \mathbf{g})\end{array}$ & $\begin{array}{l}\text { T.F.C } \\
(\mathbf{m g} / \mathbf{g})\end{array}$ & $\begin{array}{l}\text { T.T.C } \\
(\mathbf{m g} / \mathbf{g})\end{array}$ \\
\hline Bitter gourd & 92.56 & 182.61 & 34.64 & 21.19 \\
\hline Luffa & 79.03 & 112.94 & 38.02 & 25.17 \\
\hline Brinjal & 66.56 & 82.96 & 44.32 & 31.40 \\
\hline
\end{tabular}

flavonoid contents, TTC $=$ Total tannin contents

Table 4. Antibacterial activities of bitter gourd

\begin{tabular}{|c|c|c|c|c|c|c|}
\hline \multirow{2}{*}{$\begin{array}{l}\text { Microorganism } \\
\text { strains }\end{array}$} & \multicolumn{5}{|c|}{ Concentration in $\mu \mathrm{g} / \mathrm{mL}$} & \multirow{2}{*}{$\begin{array}{l}\text { MIC Value } \\
(\mu \mathrm{g} / \mathrm{mL})\end{array}$} \\
\hline & 1000 & 500 & 250 & 125 & Control & \\
\hline Escherichia coli & 16 & 8 & 3 & 0 & - & 250 \\
\hline $\begin{array}{l}\text { Staphylococcus } \\
\text { aureus }\end{array}$ & 18 & 10 & 6 & 2 & - & 125 \\
\hline
\end{tabular}

Table 5. Antibacterial activities of luffa

\begin{tabular}{|c|c|c|c|c|c|c|}
\hline \multirow{2}{*}{$\begin{array}{l}\text { Microorganism } \\
\text { strains }\end{array}$} & \multicolumn{5}{|c|}{ Concentration in $\mu \mathrm{g} / \mathrm{mL}$} & \multirow{2}{*}{$\begin{array}{l}\text { MIC Value } \\
(\mu \mathrm{g} / \mathrm{mL})\end{array}$} \\
\hline & 1000 & 500 & 250 & 125 & Control & \\
\hline Escherichia coli & 12 & 5 & 2 & 0 & - & 250 \\
\hline $\begin{array}{l}\text { Staphylococcus } \\
\text { aureus }\end{array}$ & 15 & 8 & 5 & 2 & - & 125 \\
\hline
\end{tabular}

MIC = Minimum inhibition concentration

Table 6. Antibacterial activities of brinjal

\begin{tabular}{|c|c|c|c|c|c|c|}
\hline \multirow{2}{*}{$\begin{array}{l}\text { Microorganism } \\
\text { strains }\end{array}$} & \multicolumn{5}{|c|}{ Concentration in $\mu \mathrm{g} / \mathrm{mL}$} & \multirow{2}{*}{$\begin{array}{l}\text { MIC Value } \\
(\mu \mathrm{g} / \mathrm{mL})\end{array}$} \\
\hline & 1000 & 500 & 250 & 125 & Control & \\
\hline Escherichia coli & 8 & 5 & 2 & 0 & - & 250 \\
\hline $\begin{array}{l}\text { Staphylococcus } \\
\text { aureus }\end{array}$ & 11 & 6 & 3 & 1 & - & 125 \\
\hline
\end{tabular}

\section{Evaluation of antibacterial activity}

The methanol extract of selected vegetables were tested against the two different microbes are present in Tables 4, 5 and 6 . The result revealed that the bitter gourd, Luffa and Brinjal shows excellent activity against $S$. aureus at 18 , 10,6 , and $2,15,8,5$, and 2 and $11,6,3$ and 1 $\mu \mathrm{g} / \mathrm{ml}$ at concentration range $1000,500,250$, and $125 \mathrm{ppm}$ were individual. These extracts (vegetables) also show the enhanced activity against $E$. coli, with activity as 16,8 , and $3,12,5$ and 3 , and 8,5 and $2 \mu \mathrm{g} / \mathrm{ml}$ for bitter gourd, Luffa and Brinjal at concentration 1000, 500 and $250 \mathrm{ppm}$ whereas the selected vegetables shows zero activity at $125 \mathrm{ppm}$. The (MIC) against $E$. coli 250 and for $S$. aureus was 125 $\mu \mathrm{g} / \mathrm{ml}$ determined. As a comparison study, the extract of bitter gourd revealed high activity and minimum show in brinjal respectively.

\section{DISCUSSION}

These vegetables are found to be rich sources of phenolic compounds, flavonoid and tannin contents, in quantitative analysis. The classification of phenolic content $(\mathrm{mg} / \mathrm{g})$ lies as given bitter gourd> luffa >brinjal ranging from 92.56 to $66.56(\mathrm{mg} / \mathrm{g})$. Phenolic compounds are known as regular antimicrobial (Raju and Rao, 2012). Tannins have additionally been perceived because of their remedial potential. The most elevated measure of tannins was accounted for in brinjal $(31.40 \mathrm{mg} / \mathrm{g})$. Leafy foods contain various kinds of phenolic compounds in various degrees; go about as potential antioxidant and a vital aspect for saving health and keeping away from various diseases (Krinsky and Johnson, 2005). Beforehand, in comparative investigations (Aqil et al. 2006; Ramya et al. 2011) similar values for the Total Phenolic Contents of methanol $(74.33 \pm 5.13 \mathrm{mg} / \mathrm{g})$ and ethanolic extracts $(4.9 \mathrm{mg} / \mathrm{g})$ were reported. Contrasts between the findings might be because of different conditions like temperature, area, environment, diseases and bug openness inside the species, selection of parts tried a season of taking examples, and techniques for declaration (Singh et al., 2014).

\section{CONCLUSION}

It concluded that ultra-sonic assisted base hydrolysis extraction is the most efficient method for the extraction, one can get maximum yield. The selected vegetables are very good sources of phenolic compounds, they are highly effective against microorganisms and oxidants because they contain a wide and broad range of significant organic compounds which highly beneficial for good health. It is also concluded that selected vegetables need much more attention from researchers to assess their leftover wellbeing impacts by deciding unsaturated fats, minerals, and heavy metal contamination by using different analytical techniques. 


\section{ACKNOWLEDGMENT}

We are highly thankful to the Institute of Plant Science, and Dr. M. A. Kazi Institute of Chemistry, University of Sindh, Jamshoro for instrumental facilities.

\section{AUTHOR'S CONTRIBUTION}

J. Mangi: Main author of manuscript

A. Jat: Carry all practical work

N. Soomro: Assessed anti-microbial activity of selected vegetables

A. J. Pirzada: Identification of micro-organism

A. R. Sidhu: Performed all chemical analysis of vegetables

\section{REFERENCES}

Amron, N. A. and N. Konsue. 2018. Antioxidant capacity and nitrosation inhibition of cruciferous vegetable extracts. International Food Research Journal, 25 (1): 65-73.

Andarwulan, N., R. Batari, D. A. Sandrasari, B. Bolling and $\mathrm{H}$. Wijaya. 2010. Flavonoid content and antioxidant activity of vegetables from Indonesia. Food chemistry, 121 (4): 1231-1235.

Aqil, F., I. Ahmad and Z. Mehmood. 2006. Antioxidant and free radical scavenging properties of twelve traditionally used Indian medicinal plants. Turkish Journal of Biology, (30): 177-183.

Ayaz, F. A., S. Hayırlıoglu-Ayaz, S. AlpayKaraoglu, J. Grúz, K. Valentová, J. Ulrichová and M. M. Strnad. 2008. Phenolic acid contents of kale (Brassica oleraceae L. var. acephala DC.). Extracts and their antioxidant and antibacterial activities. Food Chemistry, 107 (1): 19-25.

Boakye, A. A, F. D. Wireko-Manu, J. K. Agbenorhevi and I. Oduro. 2015. Antioxidant activity, total phenols and phytochemical constituents of four underutilized tropical fruits. International Food Research Journal, 22 (1): 262-268.

Boeing, H., C. Barth, S. Kluge and D. Walter. 2004. Tumorentstehung-hemmende und fördernde Ernährungsfaktoren. Deutsche Gesellschaft fur Ernahrung, Ed. Ernahrungs bericht, pp. 235-282.

Bouchekrit, M., H. Laouer, M. Hajji, M. Nasri, S. A. Haroutounian and S. Akkal. 2016. Essential oils from Elaeoselinumasclepium: Chemical composition, antimicrobial and antioxidant properties. Asian Pacific Journal of Tropical Biomedicine, 6 (10): 851-857.
Dasgupta, N. and B. De. 2007. Antioxidant activity of some leafy vegetables of India: A comparative study. Food chemistry, 101 (2): 471-474.

Duyn, M. and E. Pivonka. 2000. Overview of the health benefits of fruit and vegetable consumption for the dietetics professional: selected literature. Journal of the American Dietetic Association, 100 (12): 1511-1521.

Eichholz, I., S. Rohn, L. W. Kroh and S. Huyskens-Keil. 2012. Influence of location and fertilization on antioxidant activity in high bush blueberries (Vaccinium corymbosum L.). Journal of applied botany and food quality, 81 (1): 41-44.

Eme-Okafor, E. P. 2016. Effect of drying methods on the nutrient and phytochemical properties of some cultivated and wild leafy vegetables (Doctoral dissertation, M.Sc. Thesis, Department of Home Science, Nutrition and Dietetics, University of Nigeria, Nsukka).

Hu, S. H., J. C. Wang, H. F. Kung, J. T. Wang, W. L. Lee and Y. H. Yang. 2004. Antimicrobial effect of extracts of cruciferous vegetables. The Kaohsiung Journal of Medical Sciences, 20 (12): 591-599.

Isabelle, M., B. L. Lee, M. T. Lim, W. P. Koh, D. Huang and C. N. Ong. 2010. Antioxidant activity and profiles of common vegetables in Singapore. Food Chemistry, 120 (4): 993-1003.

Jaiswal, A. K., G. Rajauria, N. Abu-Ghannam and S. Gupta. 2011. Phenolic composition, antioxidant capacity and antibacterial activity of selected Irish Brassica vegetables. Natural Product Communications, 6 (9): 1934578X1100600923.

Khaw, K. T., S. Bingham, A. Welch, R. Luben, N. Wareham, S. Oakes and N. Day. 2001. Relation between plasma ascorbic acid and mortality in men and women in EPIC-Norfolk prospective study: A prospective population study. The lancet, 357 (9257): 657-663.

Krinsky, N. I. and E. J. Johnson. 2005. Carotenoid actions and their relation to health and disease. Molecular Aspects of Medicine, 26 (6): 459-516.

Laghari, A. Q., S. Memon, A. Nelofar and A. H. Laghari. 2011. Extraction, identification and antioxidative properties of the flavonoid-rich fractions from leaves and flowers of Cassia angustifolia. American Journal of Analytical Chemistry, 2 (08): 871. 
Memon, A. A., N. Memon, D. L. Luthria, A. A. Pittafi and M. I. Bhanger. 2012. Phenolic compounds and seed oil composition of Ziziphus mauritiana L. Fruit. Polish Journal of Food and Nutrition Sciences, 62 (1): 15-21.

Memon, A. A., N. Memon. M. I. Bhanger and D. L. Luthria. 2013. Assay of phenolic compounds from four species of ber (Ziziphus mauritiana L.) fruits: Comparison of three base hydrolysis procedure for quantification of total phenolic acids. Food Chemistry, 139 (1-4): 496-502.

Rahman, M. M., T. Sultana, M. Y. Ali, M. M. Rahman, S. M. Al-Reza and A. Rahman. 2017. Chemical composition and antibacterial activity of the essential oil and various extracts from Cassia sophera L. against Bacillus sp. from soil. Arabian Journal of Chemistry, 10: S2132-S2137.

Raju, J. and C. V. Rao. 2012. Diosgenin, a steroid saponin constituent of yams and fenugreek: Emerging evidence for applications in medicine. Bioactive Compounds in Phytomedicine, 125:143.

Ramya, P., J. Sudisha, D. N. Lakshmi and S. M. Aradhya. 2011. Antibacterial and Antioxidant Activities of Fenugreek (Trigonellafoenum graecum L.) leaves. Research Journal of Medicinal Plant, 5 (6): 695-705.
Schreiner, M. 2005. Vegetable crop management strategies to increase the quantity of phytochemicals. European Journal of Nutrition, 44 (2): 85-94.

Siddiqui, M. S., A. A. Memon, S. Memon and S. G. Baloch. 2017. Cuscutareflexa as a Rich Source of Bioactive Phenolic Compounds. Journal of Herbs, Spices and Medicinal Plants, 23 (2): 157-168.

Singh, P., S. P. Vishwakarma and R. L. Singh. 2014. Antioxidant, oxidative DNA damage protective and antimicrobial activities of the plant Trigonellafoenum graecum. Journal Science Food and Agriculture, 94 (12): 2497-504.

Stangeland, T., S. F. Remberg and K. A. Lye. 2009. Total antioxidant activity in 35 Ugandan fruits and vegetables. Food Chemistry, 113 (1): 85-91.

Tomas-Barberan, F. and J. Espin. 2001. Phenolic compounds and related enzymes as determinants of quality in fruit and vegetables. Journal of the Science of Food and Agriculture, 81 (9): 853-876.

Zhou, K. and L. Yu. 2006. Total phenolic contents and antioxidant properties of commonly consumed vegetables grown in Colorado. LWT-Food Science and Technology, 39 (10): 1155-1162. 